\title{
Long-term effects of liming on soil physico-chemical properties and micro-arthropod communities in Scotch pine forest
}

\author{
Henk Siepel ${ }^{1}$ (D) - Roland Bobbink ${ }^{2} \cdot$ Bas P. van de Riet ${ }^{2} \cdot$ Arnold B. van den Burg $^{3} \cdot$ Eelke Jongejans $^{1}$
}

Received: 9 January 2019 /Revised: 12 June 2019 / Accepted: 20 June 2019 / Published online: 15 July 2019

(C) The Author(s) 2019

\begin{abstract}
We tested the long-term effects of liming on soil micro-arthropods in a stand of Scotch pine on former drift sand in the Netherlands. To counteract the effects of acidification, liming was applied in increasing quantities from 0 (control), 3, 6, 9 and 18 ton $\mathrm{ha}^{-1}$ on experimental plots over the course of 1985 and 1986. Soil samples for chemical analyses and those for extraction of soil micro-arthropods were taken in October 2017, 32 years after application. Liming did restore the buffer capacity of the soil and did increase $\mathrm{pH}$ and increased plant biomass of the understory. Liming, however, also created $\mathrm{P}$ limitation, due to $\mathrm{Al}$ precipitation and an excess of free $\mathrm{Ca}$ to bind on. The consequence of the observed $\mathrm{P}$ limitation was a significant decrease in herbivorous and herbofungivorous micro-arthropods, whereas fungivorous and opportunistic herbofungivores were unaffected. $\mathrm{P}$ availability in acidified soils had become limited, due to higher $\mathrm{N}$ input that also caused acidification and due to remediation with added buffer material. Decomposition of organic matter was accelerated and increased $\mathrm{N}$ release to the system. The forest ecosystem had become P limited, where it originally was $\mathrm{N}$ limited or N and P co-limited.
\end{abstract}

Keywords Phosphate availability $\cdot$ Aluminium $\cdot$ Calcium $\cdot$ Soil fauna $\cdot$ Decomposition

\section{Introduction}

To counteract the effects of acidification due to atmospheric deposition of nitrogen and sulphur compounds from traffic, industrial and agricultural emissions, which cause severe

Electronic supplementary material The online version of this article (https://doi.org/10.1007/s00374-019-01378-3) contains supplementary material, which is available to authorized users.

Henk Siepel

henk.siepel@ru.nl

Roland Bobbink

r.bobbink@b-ware.eu

Arnold B. van den Burg

BSP@upcmail.nl

1 Department of Animal Ecology and Physiology, Institute for Water and Wetland Research, Radboud University, P.O. Box 9010, 6500 GL Nijmegen, The Netherlands

2 B-WARE Research Centre, Radboud University, P.O. Box 6558, 6503 GB Nijmegen, The Netherlands

3 Bioshere Science Productions, Onderlangs 17, 6731 BK Otterlo, the Netherlands ecological problems on a global scale (Vitousek et al. 1997; Galloway et al. 2008; Bobbink et al. 2010; Sutton et al. 2014), liming of forest soils has often been applied both in Europe (e.g. Huettl 1989; Boxman et al. 1994; Boxman and Roelofs 2006; Court et al. 2018) and in North America (e.g. Moore et al. 2012). Various effects of forest soil liming experiments on soil biota have been investigated ever since: the changed role of mycorrhizae, where liming in general decreased the relative proportion of smooth mycorrhizae in favour of hairy types (Bakker et al. 2000) and acidophilic species are replaced by more generalist ones (Rineau and Garbaye 2009). Changes in faunal groups have been evaluated by Deleporte and Tillier (1999), who report an increase in Lumbricid worm numbers in response to liming ( 1.5 ton ha ${ }^{-1}$ ) after 22 years, but did not find any difference in numbers of oribatid mites and springtails. Chagnon et al. (2001) showed a decrease of numbers of epigaeic collembolan species in the short term ( 2 years) after liming with 2 and 20 ton ha ${ }^{-1}$ carbonated lime and an increase in numbers of some endogaeic species. Geisen and Kampichler (2004) did not find any clear signal in collembolan communities after forest liming in their evaluation of the effects after 5 subsequent years of 3, 6 and 9 ton ha ${ }^{-1}$ applied lime. Hågvar and Amundsen (1981) report on the short-term effect of liming with 3 ton $\mathrm{ha}^{-1}$ of burnt lime 
$(\mathrm{CaO})$ and show oribatids to decrease in general and a number of species specifically, while numbers of a uropodid mite species increase with liming.

Among these varying results on soil fauna, only Chagnon et al. (2001) and Geisen and Kampichler (2004) provided extensive soil chemical data to possibly come to an explanation. Kreuzer (1995) reported in detail on the soil chemical processes following liming: increase of buffer capacity, which is one of the intended goals of liming, but also an increase of available $\mathrm{N}$, because of stimulated decomposition. The latter could be seen as a setback, while increased $\mathrm{N}$ load through deposition is one of the problems to solve. Haynes and Swift (1988) came to the same conclusion and, moreover, paid also attention to $\mathrm{P}$ availability in acid soils which have a high phosphate-fixing capacity. The low phosphate availability may have affected soil fauna composition and activity. The $P$ concentration in the soil explained a $72 \%$ positive relation of shifts in mass-abundance of soil animals (Mulder 2010). Vogels et al. (2017) reported a P limitation in detritivorous insects on heathlands after continuous $\mathrm{N}$ deposition, resulting in acidification and grass encroachment, causing serious nutrient imbalances. Attempts to restore the heathland by sodcutting even amplified P limitation as with the organic matter almost all $\mathrm{P}$ was removed, while $\mathrm{N}$ deposition continued, resulting in increasing $\mathrm{N}: \mathrm{P}$ ratios on the longer term. In a factorial experiment with addition of lime, phosphate or a combination of both on sod-cut, formerly grass-encroached, dry heathland, Siepel et al. (2018) showed a vast increase of herbivore numbers after $\mathrm{P}$ addition on a spodic dystrudept (see Soil Survey Staff 1999), suggesting that these animals indeed are P limited on heathlands on these mineral-poor sandy soils. Especially numbers of herbivorous grazers were stimulated (10 times more in $\mathrm{P}$ added plots compared with control plots), but less in combination with lime (only 4 times more in $\mathrm{P}$ and lime added plots than in control plots). Effects on fungivore numbers were mixed: browsers (feeding on fungal content) decreased, while the small number of fungivorous grazers increased. The effects of liming in this experiment have been discussed. Added P may be bound to the added lime and becomes less available (Haynes 1982). As this P addition experiment showed only the reaction 3 years after application, added phosphate may still be stored in plant material and may become available after a longer timespan again. So, we were looking for a situation where $\mathrm{P}$ availability may be influenced by management actions on mineral-poor sandy soils on a longer time-scale. These mineral-poor sandy soils in the Netherlands have low amounts of plant available P (e.g. Boxman et al. 1994 measured $0.035-0.141 \mathrm{mmol} \mathrm{P} \mathrm{kg}^{-1}$ in the topsoil of a humic haplorthod), where $\mathrm{P}$ may become limited rather quickly. In comparison with the data on $\mathrm{P}$ of Chagnon et al. (2001) and Geisen and Kampichler (2004), P availability in these Dutch soils was 10-30 times lower.
In the current paper, we report for the first time the combination of a complete soil biochemical analysis with microarthropods identified to the species level, which makes it possible to group the species in feeding guilds and analyse the reaction patterns of these feeding guilds to changed soil chemical properties on the long term after various levels of liming. We have revisited an old but very well-documented experiment with liming of forest soils (Dilz et al. 1988), where carbonated lime has been added in quantities of 3, 6, 9 and 18 ton $\mathrm{ha}^{-1}$. Assumed that these amounts of carbonated lime indeed decreased $\mathrm{P}$ availability, despite an increased decomposition of organic matter (Haynes 1982; Kreuzer 1995), we expect to find decreasing numbers of herbivorous microarthropods with increasing lime quantities. We expect no change in numbers of fungivorous micro-arthropods, as fungi have a much lower N:P ratio compared with plants (15 for fungi and resp. 23 and 53 for herbaceous and woody plants; Reiners 1986). Siepel and De Ruiter-Dijkman (1993) distinguished also two mixed feeding strategies on plant material and fungi: herbofungivorous grazers and opportunistic herbofungivores. As the latter were defined by trehalase activity (trehalose is a storage sugar found in temperate regions predominantly in fungi), this group also feeds on active fungi and is expected to show no relation to liming either. Decomposition is not thought to be influenced negatively, as fungivores that stimulate fungal growth (see Hanlon and Anderson 1979; Siepel and Maaskamp 1994) will not be influenced by the supposed decrease in $\mathrm{P}$ availability. On the contrary, we expect a better decomposition with liming in line with the results of Haynes and Swift (1988), Kreuzer (1995) and Court et al. (2018). So, in summary, we expect a decreasing role of micro-arthropod herbivores, but not fungivores, with the increased lime application. As fungivores have a much larger influence on decomposition than herbivores (Siepel and Maaskamp 1994), we expect an increase in the decomposition rate because of the elevated $\mathrm{pH}$.

\section{Methods and material}

\section{Study site}

The study site is a 55 years old forest stand of Scotch pine on a typic quarzipsamment (Soil Survey Staff 1999), afforested former drift sand, near the city of Harderwijk, the Netherlands $\left(52.315^{\circ} \mathrm{N}, 5.664^{\circ} \mathrm{E}\right)$. The forest stand is on a flat plane at $18 \mathrm{~m}$ a.s.l. In 1985 , a series of experiments were set up, varying from application of several types of manure (of calves and ducks), a factorial experiment with additions of $\mathrm{P}, \mathrm{Ca}, \mathrm{Mg}$ and $\mathrm{K}$, and a range of added carbonated lime in quantities of 3, 6, 9 and 18 ton $\mathrm{ha}^{-1}$ and an untreated control (see Fig. A1). All experimental plots are triplicated and $22 \times 25=550 \mathrm{~m}^{2}$ in 
size. At the start of the experiment, $\mathrm{pH}_{[\mathrm{CaCl}]}$ was around 4.1-4.2 in the mineral soil (mixed top $25 \mathrm{~cm}$ ) (Dilz et al. 1988). Carbonated lime for agricultural use, powdered, having around $2 \% \mathrm{Mg}$, was added in quantities of 3 ton (autumn 1985), 6, 9 ton (in equal amounts in autumn 1985 and 1986) and 18 ton (in equal amounts in autumn 1985, 1986 and spring 1987), to prevent vegetation damage. Thinning of the canopy was done in 2001 as regular forest management measure; no other management activities have been conducted ever since. Understory vegetation differed highly among plots as a result of liming: in the control plots wavy-hair grass (Deschampsia flexuosa), and alder buckthorn (Rhamnus frangula) are frequent and even some heather (Calluna vulgaris) can be found, while with increasing amounts of lime, species like enchanter'snightshade (Circaea lutetiana), wood avens (Geum urbanum), bittersweet (Solanum dulcamare) and bramble (Rubus fruticosus agg.) show up or become more frequent. Plant biomass of especially bramble is increased ever since the start of the liming.

\section{Soil chemical analysis}

On 16 October 2017, samples were taken for soil chemical analyses. Each sample (4 subsamples bulked and mixed, core $5 \mathrm{~cm}$ ) was taken from the top $25 \mathrm{~cm}$ of the mineral soil. We determined organic matter content by weight loss-on-ignition. Soil $\mathrm{pH}, \mathrm{NO}_{3}{ }^{-}, \mathrm{NH}_{4}{ }^{+}$and exchangeable ion concentration were determined by mixing fresh soil (17.5 g) with $50 \mathrm{~mL} 0.2 \mathrm{M} \mathrm{NaCl}$ solution. The $\mathrm{pH}$ of the solution was measured immediately using a combined $\mathrm{pH}$ electrode (radiometer and a TIM840 $\mathrm{pH}$ meter). Plant available $\mathrm{P}$ was determined by bicarbonate extraction ( $3 \mathrm{~g}$ of dry soil shaken with $100 \mathrm{~mL}$ of $0.5 \mathrm{M}$ $\left.\mathrm{NaHCO}_{3}\right)($ Olsen et al. 1954), and cation exchange capacity and base saturation by mixing an amount of dry soil equivalent of $5 \mathrm{~g}$ fresh soil in $200 \mathrm{~mL} 0.2 \mathrm{M} \mathrm{SrCl}$ (Liu et al. 2001). Soil extracts were collected under vacuum conditions with Teflon pore water samplers (rhizon, Eijkelkamp Agrisearch Equipment, The Netherlands). Total soil elemental concentrations were determined. Two hundred milligrams of soil, homogenised and dried, was digested for 17 min with $4 \mathrm{~mL} 65 \% \mathrm{HNO}_{3}$ and $1 \mathrm{~mL}$ $30 \% \mathrm{H}_{2} \mathrm{O}_{2}$ (Milestone Ethos D - Microwave Labstone) (Jin et al. 1999). Samples for Autoanalyzer Analyses were collected and stored at $-18{ }^{\circ} \mathrm{C}$ until further analysis; ICPsamples were collected and stored at $4{ }^{\circ} \mathrm{C}$. The total concentration of $\mathrm{Ca}, \mathrm{Mg}, \mathrm{Al}, \mathrm{Fe}, \mathrm{Mn}, \mathrm{P}, \mathrm{S}, \mathrm{Si}$ and $\mathrm{Zn}$ were measured with an Inductively coupled plasma spectrophotometer (ICP-OES, ICAP 6300 ARCOS MV, Spectro). $\mathrm{NO}_{3}{ }^{-}, \mathrm{NH}_{4}{ }^{+}$and $\mathrm{PO}_{4}{ }^{3-}$ concentrations were determined colorimetrically with a Seal auto-analyser III with using salicylate, hydrazin sulphate and ammoniummolybdate/ ascorbic acid reagent, respectively. $\mathrm{Cl}^{-}$was determined colorimetrically with a Bran+Luebbe auto-analyser III using mercuritiocynide. $\mathrm{Na}^{+}$and $\mathrm{K}^{+}$were determined with a Technicon Flame Photometer IV Control (Technicon Cooperation).

\section{Sampling of micro-arthropods}

On 17 October 2017, in each of the limed plots and the control plots four soil cores (Ø $5 \mathrm{~cm}$ ) of $5 \mathrm{~cm}$ depth: $100 \mathrm{~cm}^{3}$ content plus litter were sampled. The cores were taken in the middle of the plots, $1 \mathrm{~m}$ apart of each other. The cores were extracted on a Tullgren funnel for 7 days. During that period, the temperature was increased from 35 to $45^{\circ} \mathrm{C}$. Ethanol $70 \%$ was used as conservation fluid and micro-arthropods obtained were put into lactic acid $40 \%$ for clarification and identification (Siepel and van de Bund 1988). Nomenclature and identification for the main groups is according to Weigmann (2006) for Oribatida, Karg (1993) for Gamasina, Karg (1989) for Uropodina and Bretfeld (1999), Potapow (2001), Dunger and Schlitt (2011) and Jordana (2012) for Collembola. Species were grouped to feeding guilds after Siepel and De Ruiter-Dijkman (1993) in herbivorous grazers, herbivorous browsers, fungivorous grazers, fungivorous browsers (grazers feed on the cell walls as well and have respectively cellulase and chitinase activities, browsers on the contents only), opportunistic herbofungivores (including plant cell walls and fungal cell contents, i.e., cellulase and trehalase activity), herbofungivorous grazer (plant and fungal cell walls) and predators (general or specialised on nematodes or arthropods).

\section{Statistical analysis}

Soil properties (like percentage soil organic matter, moisture content, and concentration of various elements) were regressed (using $l m$ in $\mathrm{R}$ ) against the tons of added lime (i.e. treatment levels $0,3,6,9$ and 18) and separately against the $\log$ of treatment levels (after adding 1 ). For each soil property or feeding guild-specific micro-arthropod abundance variable, we compared models with logged or untransformed liming levels and selected the better fitting model based on the sum of squared residuals on the untransformed scales. The regression models of micro-arthropod abundances included plot as a random variable because multiple samples were taken per plot (i.e. mixed-effect models, lmer in R). We also constructed models with liming as a factor to see which treatments differed from the control treatment. The canonical correspondence analysis (using $c c a$ of the vegan package in R) was performed with soil chemical properties and micro-arthropod abundances per feeding guild. Additional multivariate analyses can be found in the online appendix. 


\section{Results}

\section{Soil chemistry and morphology}

Soil and especially litter layer morphology changed in the sequence of increased liming after 32 years. With an increasing amount of lime used, the litter F-horizon thickness decreased until virtually absent at 18 ton ha ${ }^{-1}$ (Figs. 1 and A2). Soil organic matter content in the top $25 \mathrm{~cm}$ mineral soil was around $3 \%$ in all treatments, while $\mathrm{pH}(\mathrm{NaCl})$ increased with liming from 3.5 (control) to 4.9 (18 ton ha ${ }^{-1}$ ) (Fig. 2). Base saturation increased with the amount of liming from $<10 \%$ (control) to around $90 \%$ (18 ton ha ${ }^{-1}$ ), which is predominantly exchangeable $\mathrm{Ca}^{2+}$ and to a lesser extent $\mathrm{Mg}^{2+}$ (Fig. 3). Free $\mathrm{Al}^{3+}$ decreased with increasing liming and the $\mathrm{Al}^{3+} / \mathrm{Ca}^{2+}$ ratio even more so (Fig. 4). Nitrogen, both as $\mathrm{NO}_{3}{ }^{-}$as well as $\mathrm{NH}_{4}{ }^{+}$ forms, increased with liming, but plant available $\mathrm{P}\left(\mathrm{P}_{\mathrm{Olsen}}\right)$ decreased (Fig. 5). Detailed soil chemistry data can be found in Siepel et al. (2019).

\section{Soil micro-arthropods}

In total, 129 micro-arthropod species have been identified (in 23,487 individuals). Mites formed the majority (87.5\%), followed by springtails (11.7\%); of the smaller groups of Protura, Diplura, Symphya and Pseudoscorpionida, one species per group was found ( $0.8 \%$ of total micro-arthropods). The abundance of micro-arthropods was highest in the control

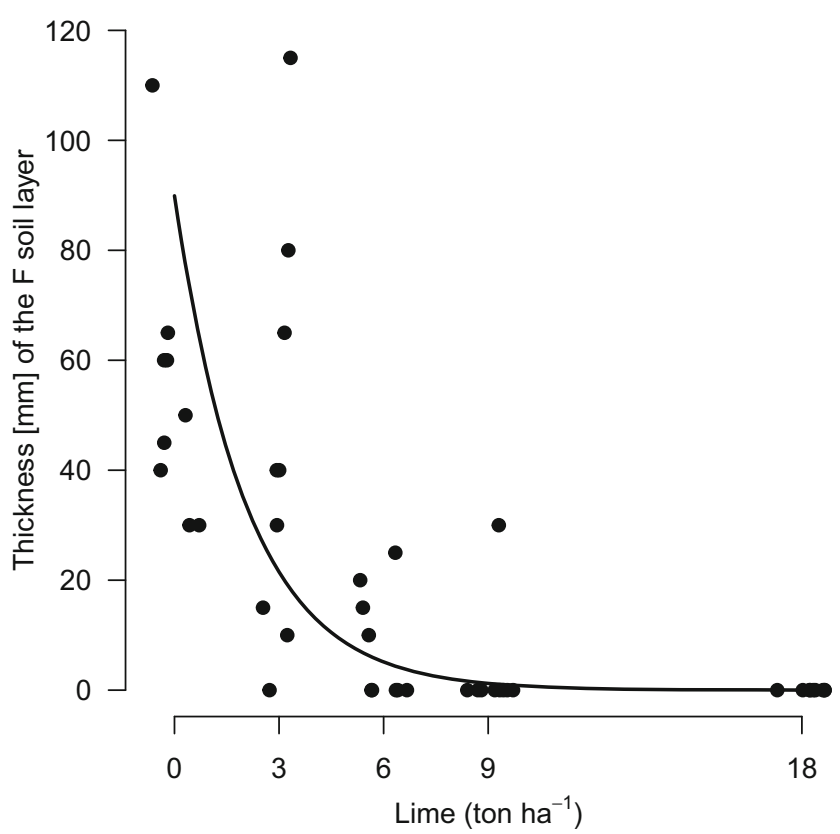

Fig. 1 Thickness (mm) of the F soil layer. Three samples were taken in each of the 15 plots. The effect of liming is highly significant $(z=-5.37$, $p<0.001$ ) in the fitted generalized linear mixed-effect model (log link and plot as a random variable). Points are spread out horizontally for visual clarity
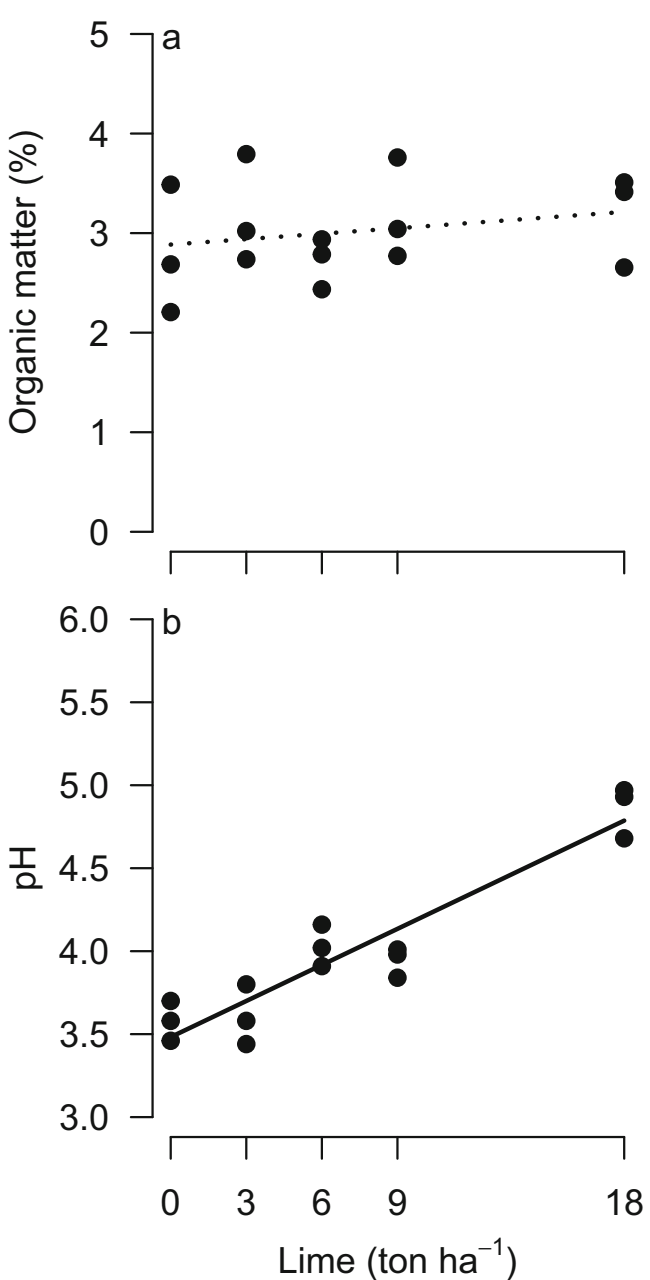

Fig. 2 a Average soil organic matter (\%) and $\mathbf{b} \mathrm{pH}$ in each of the 15 plots. The $\mathrm{pH}$ significantly $(t=9.76, p<0.001)$ increased with liming. Organic matter showed no relationship $(t=0.906, p=0.381)$ with the amount of applied lime. Also, none of the treatment levels differed significantly from the controls for organic matter. For $\mathrm{pH}$, the 6,9 and 18 ton ha ${ }^{-1}$ treatments differed significantly from the controls

plots $\left(255,250 \pm 37,811\right.$ ind $\left.\mathrm{m}^{-2}\right)$ and lowest in the plots with 18 -ton lime $\left(161,334 \pm 5779\right.$ ind $\left.\mathrm{m}^{-2}\right)$. Species richness, diversity and evenness did not differ significantly along the liming gradient (Figs. A3-A5). The PCA (Fig. A6) showed the soil chemical variables of the sampled plots. The first principal axis explained $63.0 \%$ of the total variance and covers primarily the effects of added lime (increased $\mathrm{pH}, \mathrm{Ca}^{2+}, \mathrm{Mg}^{2+}$ and $\mathrm{NO}_{3}{ }^{-}$and decreased $\mathrm{Al}^{3+}$ and $\mathrm{P}$ ). The second principal axis explained another $19.8 \%$ and covers soil organic matter and $\mathrm{NH}_{4}{ }^{+}$). In the CCA performed at the level of feeding guilds (Fig. 6), the first axis represented $49.5 \%$ of the total variance, the second axis $24.6 \%$. Soil chemistry explained $55.9 \%$ of the variance, with $\mathrm{P}$ and $\mathrm{Al}$ being strongly associated with the first axis, $\mathrm{N}$ to a lesser extent with the second axis, and $\mathrm{Ca}, \mathrm{pH}$ and $\mathrm{Mg}$ with both axes. Numbers of herbivorous micro-arthropods are presented in Fig. 7a. Decrease of numbers with increasing quantities of lime was highly significant 


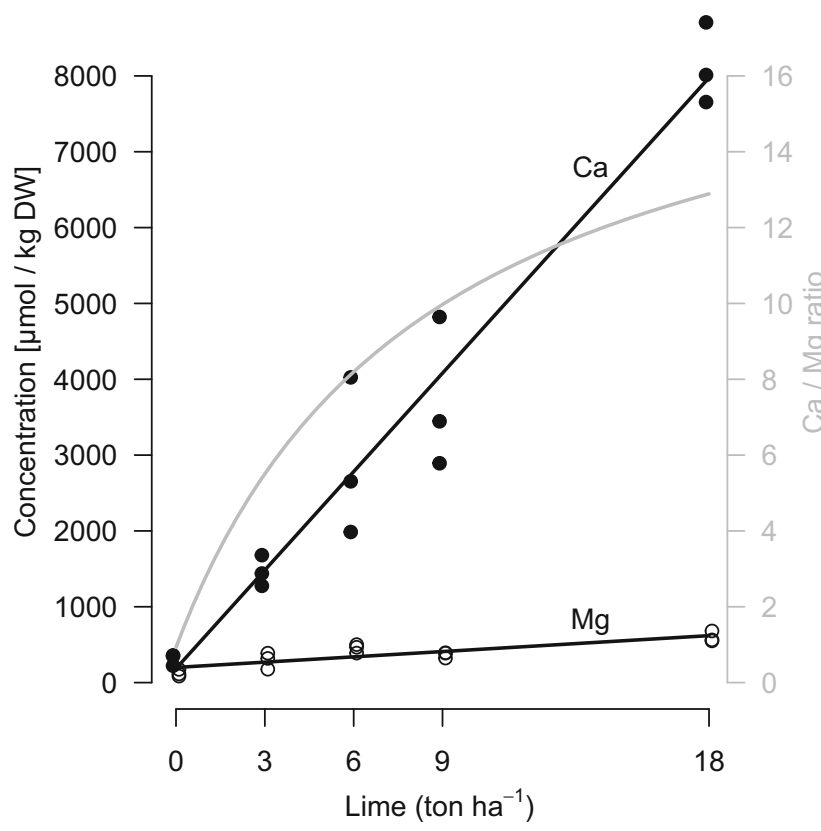

Fig. 3 Calcium and $\mathrm{Mg}$ concentrations in each of the 15 plots. Both significantly $(t>3.85, p<0.001)$ increased with liming (black lines), while the $\mathrm{Ca} / \mathrm{Mg}$ ratio (grey line) of the modeled concentrations went up from 0.93 in the control plots to 12.89 at 18 ton lime per hectare. When liming was treated as a factor, all liming treatments differed significantly from the controls, except for the 3 ton $\mathrm{ha}^{-1}$ addition in the $\mathrm{Ca}$ model

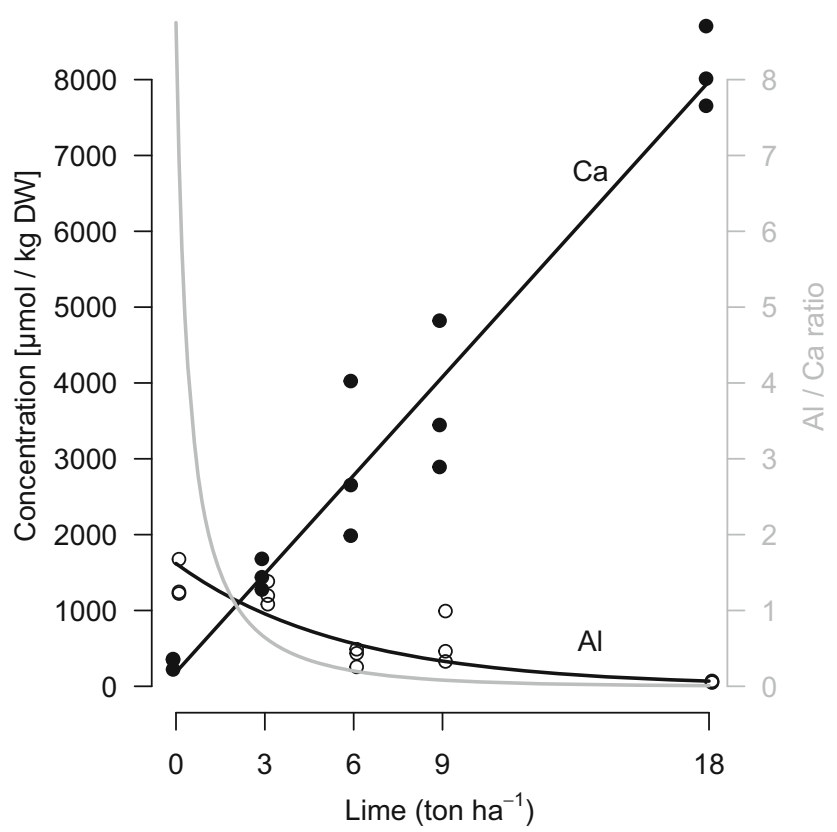

Fig. 4 Calcium and $\mathrm{Al}$ concentrations in each of the 15 plots. While $\mathrm{Ca}$ significantly increased with liming (black line, $t=16.16, t<0.001$ ), Al decreased (black line, $t=-9.63, p<0.001$ ). The $\mathrm{Al} / \mathrm{Ca}$ ratio (grey line) of the modeled concentrations decreased from 8.75 in the control plots to 0.0086 at 18 ton lime ha ${ }^{-1}$. When liming was included as a factor, the 6,9 and 18 ton lime ha ${ }^{-1}$ treatments differed significantly from the controls, in both the $\mathrm{Ca}$ and the $\mathrm{Al}$ model
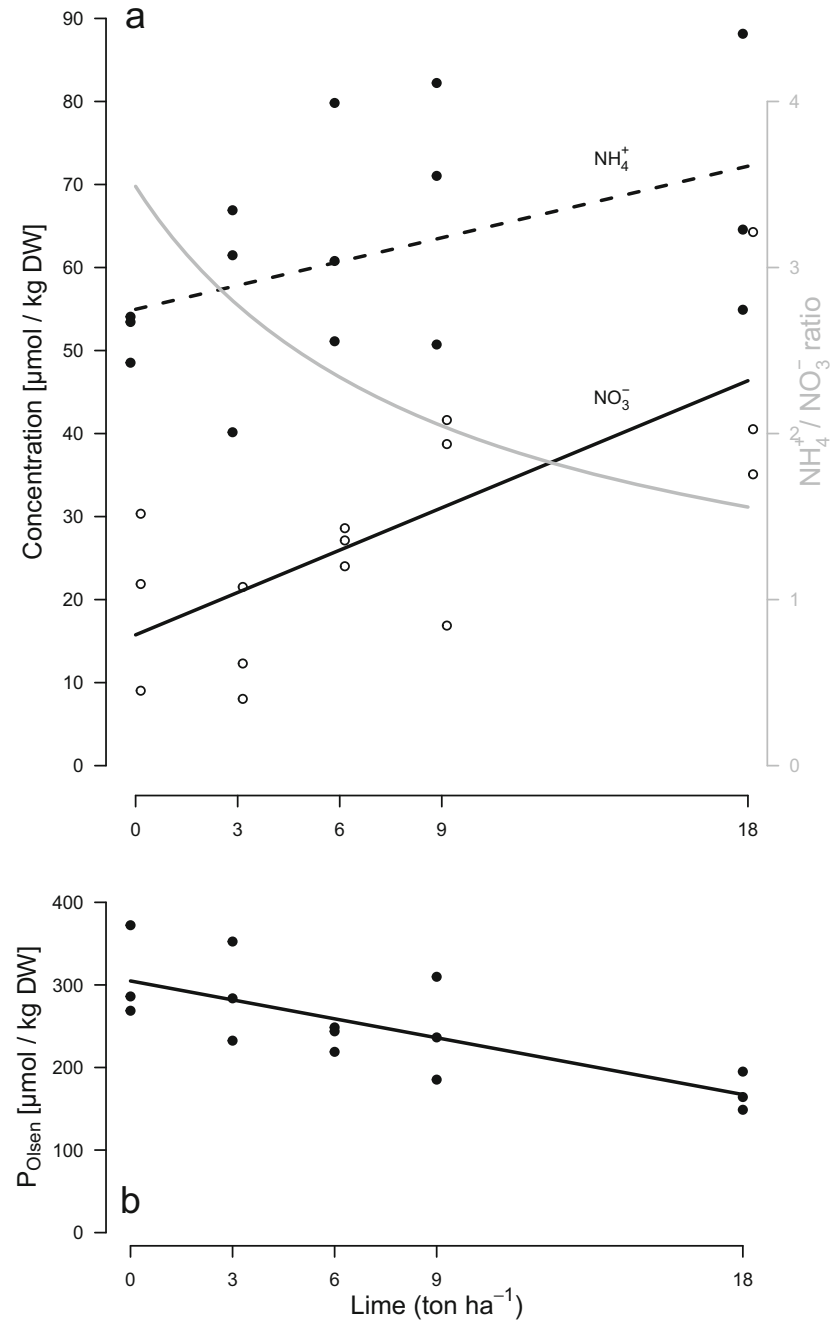

Fig. 5 a Ammonium and $\mathrm{NO}_{3}^{-}$and $\mathbf{b} \mathrm{P}_{\text {Olsen }}$ concentrations in each of the 15 plots. Nitrate increased significantly with liming (black, uninterrupted line, $t=3.92, p=0.0018$, while $t=1.81$ and $p=0.094$ for $\mathrm{NH}_{4}^{+}$). The $\mathrm{NH}_{4}^{+} / \mathrm{NO}_{3}^{-}$ratio (grey line) of the modeled concentrations decreased from 3.49 in the control plots to 1.56 at 18 ton lime ha ${ }^{-1}$. $\mathrm{P}_{\text {Olsen }}$ decreased significantly $(t=-4.19, p=0.0011)$ with added lime. When liming was included as a factor in the models, only the 18 ton lime ha ${ }^{-1}$ treatment (for $\mathrm{NO}_{3}^{-}$and $\mathrm{P}_{\mathrm{Olsen}}$ ) differed significantly from the controls in the case of $\mathrm{NO}_{3}^{-}$, while none of the treatment effects were significant for $\mathrm{NH}_{4}^{+}$

$(t=-4.5)$. Dominant species here are the oribatid mites Atropacarus striculus (C.L. Koch, 1836), Steganacarus magnus (Nicolet, 1855) and Platynothrus peltifer (C.L. Koch, 1839), the collembolan Lepidocyrtus lignorum (Fabricius, 1793) and the symphylan Symphylellopsis subnuda (Hansen, 1903). Fungivores, however, did not decrease with increasing lime quantities (Fig. 7b): $t=0.7$ (no relation with lime quantities). All dominant species here were oribatid mites: the fungivorous grazers Eniochthonius minutissimus (Berlese, 1904), Oppiella nova (Oudemans, 1902) and Punctoribates punctum (C.L. Koch, 1839) and the fungivorous browsers Suctobelbella acutidens (Forsslund, 1941) and S. subcornigera (Forsslund, 1941). In 


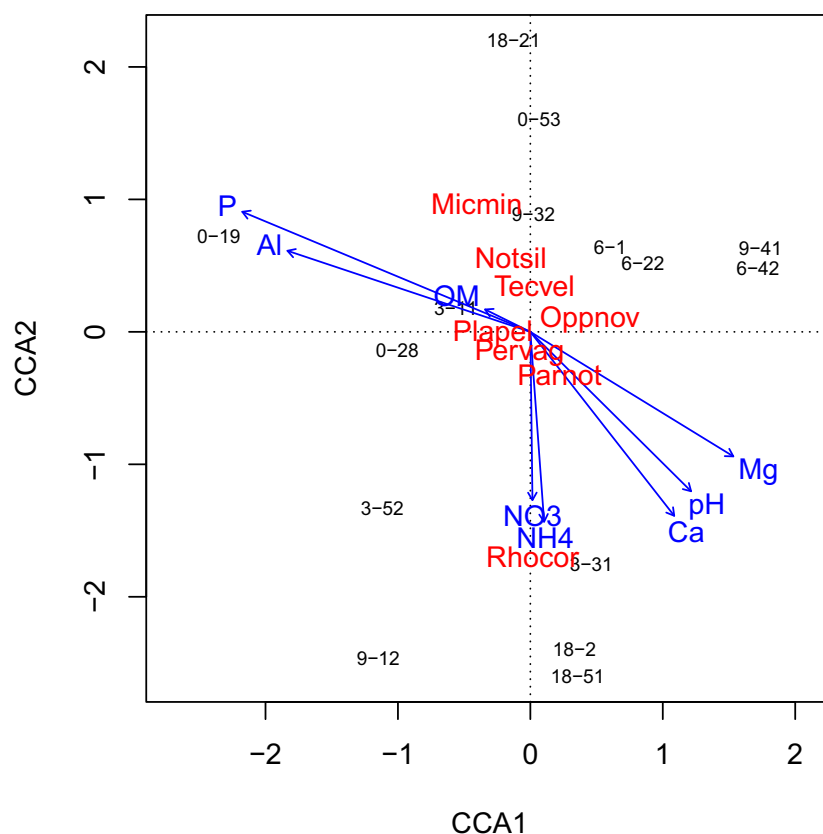

Fig. 6 Canonical correspondence analysis of the micro-arthropod communities (organised by feeding guilds) and soil chemical properties. Species abundances were averaged per plot and summed per feeding guild prior to analysis. Numbers indicate liming treatment and plot number (see Fig. A1), respectively. The first CCA axis represents $49.5 \%$ of the variation, the second axis $24.6 \%$. The soil chemical properties explained $55.9 \%$ of the variance. Afterwards, eight abundant species were added to the plot: the herbivorous grazer Platynothrus peltifer (Plapel), the fungivorous grazers Oppiella nova (Oppnov), the fungivorous browser Parisotoma notabilis (Parnot), the herbofungivorous grazers Nothrus silvestris (Notsil) and Microtritia minima (Micmin), the opportunistic herbivorous grazer Tectocepheus velatus (Tecvel) and the general predators Rhodacarus coronatus (Rhocor) and Pergamasus vagabundus (Pervag)

Fig. 7c and d, results of the mixed feeding guilds are presented, where the herbofungivorous grazers show a significant negative relationship with liming (Fig. $7 \mathrm{c}, t=-4.2$, dominant species: the oribatids Nothrus silvestris (Nicolet, 1855) and Rhyssotritia duplicata (Grandjean, 1953)), whereas the opportunistic herbofungivores show no relationship with liming (Fig. $7 \mathrm{~d}, t=-1.4$, dominant species: the oribatids Adoristes ovatus (C.L. Koch, 1839) and Tectocepheus velatus (Michael, 1880)). Data on the abundance of all micro-arthropod species in this project can be found in Siepel et al. (2019).

\section{Discussion}

\section{Soil chemistry and morphology}

Liming seems to meet its initial goal of increasing the $\mathrm{pH}$ and increasing the base saturation. With increasing $\mathrm{pH}$ Al precipitates, and thus the concentration of free $\mathrm{Al}^{3+}$ is decreasing. Along with an increase of free $\mathrm{Ca}^{2+}$, the $\mathrm{Al}^{3+} / \mathrm{Ca}^{2+}$ ratio drops significantly and one may assume that the negative effects of acidification have been largely alleviated. However, there is also a downside of this ecological restoration technique: the amount of free $\mathrm{Ca}^{2+}$ is inconceivably high for a Scotch pine stand on former drift sand (Boxman and Roelofs 2006 give values of around $100 \mu \mathrm{M} \mathrm{kg}^{-1}$, whereas our highest values are above $8000 \mu \mathrm{M} \mathrm{kg}^{-1}$, Fig. 3), which may lead to a competition in uptake with $\mathrm{Mg}^{2+}$ for plants and possible chlorosis (at 18 ton $\mathrm{ha}^{-1} \mathrm{Ca} / \mathrm{Mg}$ ratio > 14 in plot 21, compared with 1.9 in control plot 19). Another side effect is the increase of $\mathrm{NO}_{3}{ }^{-}$ and $\mathrm{NH}_{4}{ }^{+}$. As the recent acidification is caused by increased $\mathrm{N}$ deposition, an increase of freely available $\mathrm{N}$ is quite undesirable, as this enhances the eutrophication by $\mathrm{N}$ compounds. This increase has been reported before (Haynes and Swift 1988; Kreuzer 1995; Court et al. 2018) and is the result of increased decomposition of plant material: the inhibiting effect of acid remnants of incomplete decomposition is buffered by the dissolution of lime. The ratio $\mathrm{NH}_{4}{ }^{+} / \mathrm{NO}_{3}{ }^{-}$is decreasing, which can be seen as positive, as more plants are able to take up $\mathrm{NO}_{3}{ }^{-}$than $\mathrm{NH}_{4}{ }^{+}$(Van den Berg et al. 2005, De Graaf et al. 2009), which may increase understory plant diversity. Another negative effect of liming is apparently the decrease of plant available $\mathrm{PO}_{4}{ }^{3-}$. Soil phosphate chemistry is quite complicated and many results seem contradictory if $\mathrm{pH}, \mathrm{P}$ concentration itself and free $\mathrm{Ca}^{2+}$ concentrations are not taken into account. The process, as we consider here, has been started by the acidification process, setting free $\mathrm{Al}^{3+}$, (see control plots for concentration without buffering). Raising $\mathrm{pH}$ from this point may result in precipitation of $\mathrm{Al}^{3+}$ with $\mathrm{PO}_{4}{ }^{3-}$, the new formation of amorphous Al-P bindings $(\mathrm{Al}(\mathrm{OH}) 2 \mathrm{H} 2 \mathrm{PO} 4$; stable at $2.5<\mathrm{pH}<8.5$ ), and the high concentration of free $\mathrm{Ca}^{2+}$ may lead to the formation of new hydroxyapatite $\left(\mathrm{Ca}_{5}\left(\mathrm{PO}_{4}\right)_{3} \mathrm{OH} .2 \mathrm{H}_{2} \mathrm{O}\right)$ (Haynes 1982). Also Aarnio et al. (2003) found a binding effect of liming as they state that the amount of soluble $\mathrm{P}$ was less in limed than in non-limed apatite-treated soils; these soils had comparable levels of $\mathrm{PO}_{4}{ }^{3-}$ in an acid soil (mineral coarse podzolic sand, $\mathrm{pH}=3.6$, measured in water, $\left.\left[\mathrm{PO}_{4}{ }^{3-}\right]=0.16 \mu \mathrm{mol} \mathrm{kg}{ }^{-1}\right)$. At higher $\mathrm{pH}$ levels, no effect on phosphate availability is seen (Chagnon et al. 2001; $\mathrm{pH}=4.2$, measured in water; Geisen and Kampichler 2004, $\mathrm{pH}=4.2-6.2$, measured in $0.01 \mathrm{M} \mathrm{CaCl}_{2}$; Court et al. 2018; $\mathrm{pH}=4.5$, measured in water). The $\mathrm{pH}$ measured in $0.01 \mathrm{M} \mathrm{CaCl} 2$ is about 0.6 lower than measured in water (Blume et al. 2010). As McDowell et al. (2002) state: Al solubility plays a major role in determining $\mathrm{P}$ solubility and consequently $\mathrm{P}$ release to the soil solution. Moreover, the decrease of free $\mathrm{Al}^{3+}$ relieves its toxic effect on $\mathrm{PO}_{4}{ }^{3-}$ uptake by plant roots (De Graaf et al. 1997). Also, the enhanced mineralisation of the organic layer may have released more P (Haynes 1982). However, as we see the strong development of understory vegetation (especially bramble) with increasing lime addition, the plant may have acquired and stored more $\mathrm{P}$ from the soil at higher levels of liming. 
Fig. 7 Number of microarthropods in each of the samples. a Herbivores (both browsers and grazers). b Fungivorous (both browsers and grazers). $\mathbf{c}$

Herbofungivorous grazers. d Opportunistic herbofungivores. Solid lines indicate a significantly negative effect of liming in the fitted mixed-effect model (samples nested within plots, $t$-statistics of the four analysis are $4.461,-0.728,-4.188$ and 1.402 , respectively). Dashed lines indicate non-significant effects of liming. Please note the differently scaled $y$-axes. When liming was included as a factor in the analyse, all treatments differed significantly from the controls in a and $\mathbf{c}$, none in $\mathbf{b}$ and only 6 ton $\mathrm{ha}^{-1}$ in d

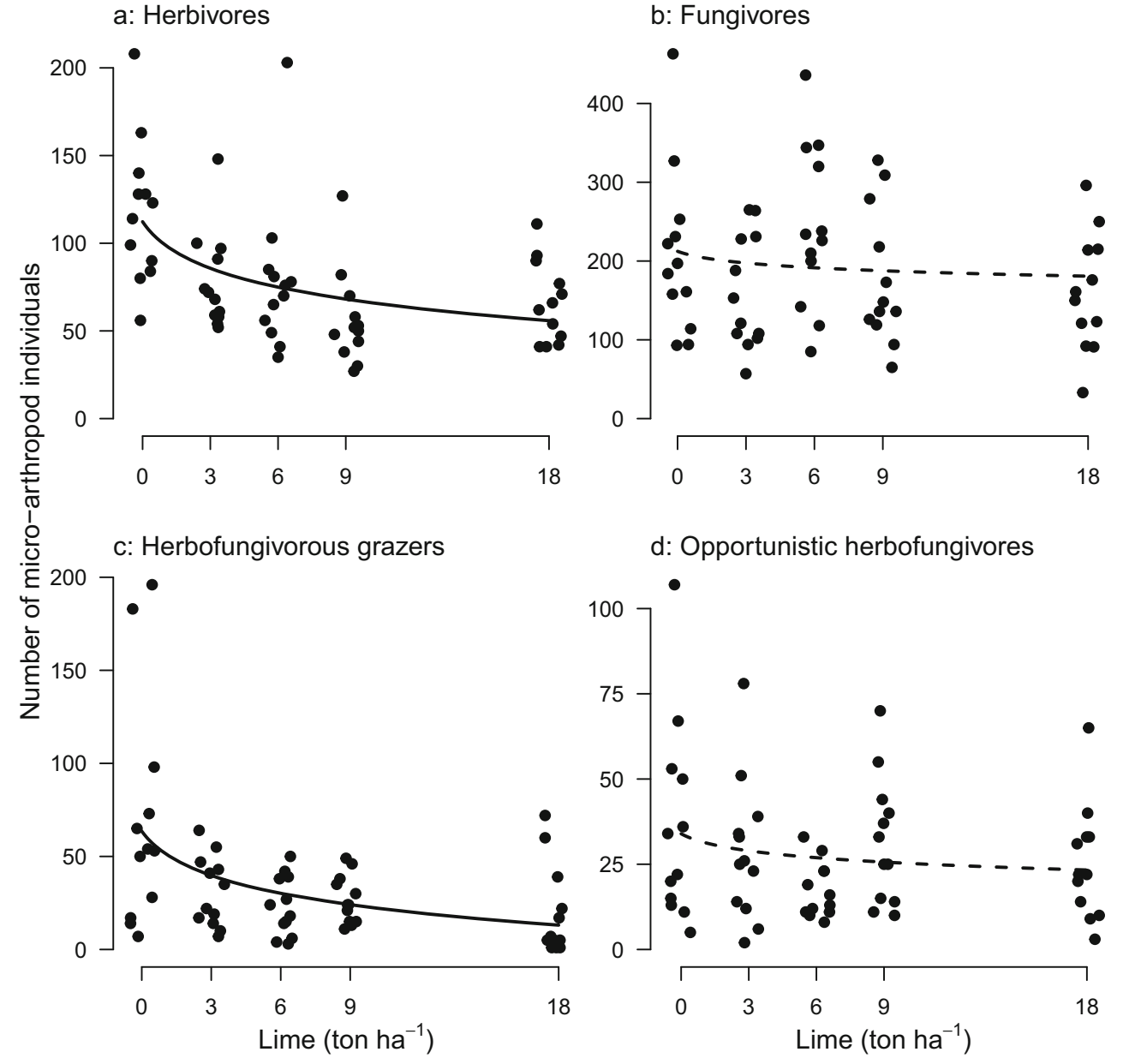

Increased decomposition, seen from increased $\mathrm{NO}_{3}{ }^{-}$and $\mathrm{NH}_{4}{ }^{+}$concentrations in soil with increasing amounts of lime supplied, can also be seen morphologically: the litter layer is almost completely vanished in the 18 ton $^{\mathrm{ha}^{-1}}$ (Fig. A2) and gradually decreases with increasing amounts of lime (Fig. 1). Where in the control site a tiny spodic horizon develops in the top soil (just below the litter layer, see Fig. A2), in the 18 ton $\mathrm{ha}^{-1}$ organic matter is completely mixed with the top soil, creating a small A1 horizon. Especially macrofauna is active in the limed sites, feeding on the combination of fungi and organic matter (e.g. larvae of Mycetophilidae, Bibionidae and Tipulidae). Abundances of these larvae can temporarily be very high. In comparable situations 74 specimens of Dilophus febrilis (Linnaeus, 1758) were found per $10 \mathrm{~g}$ organic matter (Siepel 1990). Earthworms are not present in these young afforested drift sand soils.

\section{Consequences for soil micro-arthropods}

Differences in sampling depth between the standard protocol for micro-arthropods (Siepel and Van de Bund 1988) and that for chemical analyses (Dilz et al. 1988), respectively top 5 and $25 \mathrm{~cm}$, are inconsequential. However, the majority of soil micro-arthropods is found in the top $5 \mathrm{~cm}$ (around 95\% in Ducarme et al. 2004) and probably even more in our soil type. Sampling the top $25 \mathrm{~cm}$ for soil chemistry may have diluted the data somewhat compared with when we would have measured just the top $5 \mathrm{~cm}$. The presented patterns in soil chemistry can therefore be considered conservative. The decline of the F-layer could be seen as the cause of the lower number of micro-arthropods one could argue. However, all feeding guilds then should decrease in about the same way. We see a clear pattern of decrease in the herbivores but not in the fungivores; the latter is more or less constant throughout the range of liming. Moreover, two mixed feeding guilds in which both plant and the fungal matter is digested show comparable patterns. Opportunistic herbofungivores that digest plant cell walls and fungal cell contents (these have both a cellulase and trehalase activities; Siepel and De Ruiter-Dijkman 1993) act like fungivores and do not show a significant decrease with liming. These mites gather $P$ from active living fungal material by definition. On the other hand, the herbofungivorous grazers that digest both plant cell walls and fungal cell walls appear to feed on dead fungal material next to plant organic matter (Siepel and De Ruiter-Dijkman 1993). Where living fungal hyphae contain a N:P ratio of 15 (Reiners 1986), dead 
hyphae, or fungal cell walls alone have hardly any P left. P amounts of fungal cell walls are between 0.3 (Aspergillus sp.; Ruiz-Herrera 1967) and $0.7 \%$ (Penicillium notatum; Applegarth 1967). So feeding on dead fungal material in combination with plant organic matter yield as much phosphate as just herbivory and herbofungivorous grazers decline significantly with liming comparable with herbivores. It appears from the chemical data that the probable causal factor of the decline of the numbers of herbivorous (and herbofungivorous) micro-arthropods is in the decreasing availability of phosphate. Hågvar and Amundsen (1981) found a decrease of Nothrus silvestris, Nanhermannia sp. and Sellnickochthonius zelawaiensis all herbofungivorous grazers, and also a decrease of the opportunistic herbofungivore Tectocepheus velatus in a study on liming of heathland 3 years after application, although these numbers were low. Siepel et al. (2018) found a slight increase of opportunistic herbofungivores after the same short term after liming of a sod-cut heathland. Chagnon et al. (2001) found a decrease of both epigaeic and endogaeic Collembola 2 years after liming, but they did not differentiate in herbivores or fungivores, just as Geisen and Kampichler (2004), who did not find any pattern in species composition 5-9 years after repeated liming. Collembola in our study follows the general pattern of the micro-arthropod total, but less strong compared with the mites.

In conclusion, long-term effects of liming confirm earlier results of increased $\mathrm{pH}$ and buffer capacity as aimed for, and also increased decomposition with higher amounts of available N. Availability of phosphate appears to decrease with liming in nutrient-poor sandy soils, which is enhanced by previous aluminium release through acidification. When this limitation cascades in the food web, one might expect effects on predatory species having less prey to feed on (Michalko et al. 2018). So, liming does not restore the original type of forest as it was before $\mathrm{N}$ deposition and acidification, but it pushes the system in a completely new direction, with a change in plant species composition in the understory and limitation of phosphate which might have consequences for animal life when applied on a larger scale. Alternatives for liming, such as finely ground igneous rocks (rock powder), might overcome a potential shock-effect, but probably has the same long-term effect on phosphate availability, as this is caused by the earlier release (acid deposition) and precipitation of aluminium (after buffering), and the excess of buffer material for $\mathrm{P}$ to bind on. To lift the $\mathrm{P}$ limitation with $\mathrm{P}$ addition, either as part of some rock powders, either as extra mineral addition, may give rise to unwanted situations as well, as long as the ongoing $\mathrm{N}$ deposition is much too high. In the near future, we must elucidate the complex interaction of rock powder addition (potentially in combination with mineralbound $\mathrm{P}$ addition), on soil biochemical and biological processes. Especially the role of a diversity of ecto- and ericoid mycorrhizas must be explained as a supplier of organic bound $\mathrm{P}$ in interaction with arbuscular mycorrhizas, when mineralbound $\mathrm{P}$ is added as well. Also, a detailed $\mathrm{P}$ fractionation is necessary to explain the total contents and availability of $\mathrm{P}$ in different soil compartments.

Acknowledgements We thank the management, especially Roel Janssen and Gerjan van Boven (municipality Harderwijk), for their cooperation and help with tracing all documentation and field sites.

Funding information RB, RvdR and AvB were financially supported by OBN grant monitoring-17-DZ, thanks to the Ministry of Economic Affairs and BIJ12.

Open Access This article is distributed under the terms of the Creative Commons Attribution 4.0 International License (http:// creativecommons.org/licenses/by/4.0/), which permits unrestricted use, distribution, and reproduction in any medium, provided you give appropriate credit to the original author(s) and the source, provide a link to the Creative Commons license, and indicate if changes were made.

\section{References}

Aarnio T, Räty M, Martikainen PJ (2003) Long-term availability of nutrients in forest soil derived from fast- and slow-release fertilizers. Plant Soil 252:227-239

Applegarth DA (1967) The cell wall of Penicillium notatum. Arch Biochem Biophys 120:471-478

Bakker MR, Garbaye J, Nys C (2000) Effect of liming on the ectomycorrhizal status of oak. Forest Ecol Manag 126:121-131

Blume H-P, Brümmer GW, Horn R, Kandeler E, Kögel-Knabner I, Kretzschmar R, Stahr K, Wilke B-M (2010) Scheffer/ Schachtschabel: Lehrbuch der Bodenkunde. Springer Spektrum, Berlin, Heidelberg

Bobbink R, Braun S, Nordin A, Power S, Schütz K, Strengbom J, Weijters M, Tomassen H (2010) Review and revision of empirical critical loads and dose-response relationships. Proceedings of an expert workshop, Noordwijkerhout, RIVM-report 680359002, Bilthoven, Netherlands, pp1-246

Boxman AW, Cobben PLW, Roelofs JGM (1994) Does (K+Mg+Ca+P) fertilization lead to recovery of tree health in a nitrogen stressed Quercus rubra L. stand? Environ Pollut 85:297-303

Boxman AW, Roelofs JGM (2006) Effects of liming, sod-cutting and fertilization at ambient and decreased nitrogen deposition on the soil solution chemistry in a Scots pine forest in the Netherlands. Forest Ecol Manag 237:237-244

Bretfeld G (1999) Symphypleona. In: Dunger W (ed) Synopses on Palaearctic Collembola, Vol. 2 Staatliches Museum für Naturkunde Görlitz, Germany, pp1-318

Chagnon M, Paré D, Hébert C, Camiré C (2001) Effects of experimental liming on collembolan communities and soil microbial biomass in a southern Quebec sugar maple (Acer saccharum Marsh.) stand. Appl Soil Ecol 17:81-90

Court M, van der Heijden G, Didier S, Nys C, Richter C, Pousse N, SaintAndré L, Legout A (2018) Long-term effects of forest liming on mineral soil, organic layer and foliage chemistry: insights from multiple beech experimental sites in Northern France. Forest Ecol Manag 409:872-889

de Graaf MCC, Bobbink R, Verbeek PJM, Roelofs JGM (1997) Aluminium toxicity and tolerance in three heathland species. Water Air Soil Pollut 98:229-239 
de Graaf MCC, Bobbink R, Smits NAC, van Diggelen R, Roelofs JGM (2009) Biodiversity, vegetation gradients and key biogeochemical processes in the heathland landscape. Biol Conserv 142:2191-2201

Deleporte S, Tillier P (1999) Long-term effects of mineral amendments on soil fauna and humus in an acid beech forest floor. Forest Ecol Manag 118:245-252

Dilz K, Hekstra A, van Diest A, van den Burg J (1988) Bemestingsproef in het gemeentebos van Harderwijk [in Dutch]. Jaarverslag 1987. Gemeente Harderwijk, Christelijk Agrarisch Hogeschool Dronten, Vakgroep Bodemkunde en Plantenvoeding LU Wageningen, Nederlands Meststoffeninstituut Den Haag

Ducarme X, Andre HM, Wauthy G, Lebrun P (2004) Are there real endogeic species in temperate forest mites? Pedobiologia 48:139 147

Dunger W, Schlitt B (2011) Tullbergiidae. In: Dunger W (ed) Synopses on Palaearctic Collembola, Vol. 6/1 Senckenberg Museum of Natural History Görlitz, 1-168

Galloway JN, Townsend AR, Erisman JW, Bekunda M, Cai Z, Freney J, Martinelli LA, Seitzinger SP, Sutton MA (2008) Transformation of the nitrogen cycle: recent trends, questions, and potential solutions. Science 320:889-892

Geisen V, Kampichler C (2004) Limits to the bioindication potential of Collembola in environmental impact analysis: a case study of forest soil-liming and fertilization. Biol Fertil Soils 39:383-390

Hanlon RDG, Anderson JM (1979) The effects of on the microflora of Collembola grazing on microbial activity in decomposing leaf litter. Oecologia 38:93-99

Haynes RJ (1982) Effects of liming on phosphate availability in acid soils. Plant Soil 68:289-308

Haynes RJ, Swift RS (1988) Effects of lime and phosphate additions on changes in enzyme activities, microbial biomass and levels of extractable nitrogen, sulphur and phosphorus in an acid soil. Biol Fertil Soils 6:153-158

Huettl RF (1989) Liming and fertilization as mitigating tools in declining forest ecosystems. Water Air Soil Pollut 44:93-118

Hågvar S, Amundsen T (1981) Effects of liming and artificial acid rain on the mite (Acari) fauna in coniferous forest. Oikos 37:7-20

Jin Q, Liang F, Zhang H, Zhao L, Huan Y, Song D (1999) Application of microwave techniques in analytical chemistry. Trends Anal Chem $18: 479-484$

Jordana R (2012) Capbryinae and Entomobryini. In: Dunger W (ed) Synopses on Palaearctic Collembola, Vol. 7/1 Senckenberg Museum of Natural History Görlitz, 1-390

Karg W (1989) Acari (Acarina), Milben, Unterordnung Parasitiformes (Anactinoichaeta), Uropodina Kramer, Schildkrötchenmilben. Die Tierwelt Deutschlands 67. Teil, VEB Gustav Fischer Verlag, Jena, $1-203$

Karg W (1993) Acari (Acarina), Milben, Parasitiformes (Anactinochaeta), Cohors Gamasina Leach, Raubmilben. Die Tierwelt Deutschlands 59. Teil, 2. Überarbeitete Auflage, VEB Gustav Fischer Verlag, Jena, 1-523

Kreuzer K (1995) Effects of forest liming on soil processes. Plant Soil 168-169:447-470

Liu CL, Wang MK, Yang CC (2001) Determination of cation exchange capacity by one-step soil leaching column method. Commun Soil Sci Plan 32:2359-2372

McDowell RWM, Brookes PC, Mahieu N, Poulton PR, Johnston AE, Sharpley AN (2002) The effect of soil acidity on potentially mobile phosphorus in a grassland soil. J Agric Sci 139:27-36

Michalko R, Kula E, Košulič O (2018) Liming alters body size distribution in a community of epigeic spiders in birch forest (Betula pendula Roth). Ann Forest Sci 2018:75-92
Moore J-D, Ouimet R, Duchesne L (2012) Soil and sugar maple response 15 years after dolomitic lime application. Forest Ecol Manag 281: $130-139$

Mulder C (2010) Soil fertility controls the size-specific distribution of eukaryotes. Ann N Y Acad Sci 1195:E74-E81

Olsen SR, Cole CV, Watanabe FS, Dean LA (1954) Estimation of available phosphorus in soils by extraction with sodium bicarbonate. US Dept Agr Circ 939

Potapow M (2001) Isotomidae. In Dunger W (ED) Synopses on Palaearctic Collembola, Vol. 3 Staatliches Museum für Naturkunde Görlitz, 1-603

Reiners WA (1986) Complementary models for ecosystems. Am Nat 127:59-73

Rineau F, Garbaye J (2009) Effects of liming on ectomycorrhizal community structure in relation to soil horizons and tree hosts. Fungal Ecol 2:103-109

Ruiz-Herrera J (1967) Chemical components of the cell wall of Aspergillus species. Arch Biochem Biophys 122:118-125

Siepel H (1990) Decomposition of leaves of Avenella flexuosa and microarthropod succession in grazed and ungrazed grasslands. I Succession of microarthropods. Pedobiologia 34:19-30

Siepel H, Bobbink R, van de Riet BP, van den Burg AB, Jongejans E (2019) Data from: Long-term effects of liming on soil physicochemical properties and micro-arthropod communities in Scotch pine forest. DANS EASY. https://doi.org/10.17026/dans-z6b-4qc3

Siepel H, de Ruiter-Dijkman EM (1993) Feeding guilds of oribatid mites based on carbohydrase enzyme activities. Soil Biol Biochem 25: 1491-1497

Siepel H, Maaskamp F (1994) Mites of different feeding guilds affect decomposition of organic matter. Soil Biol Biochem 26:1389-1394

Siepel H, van de Bund CF (1988) The influence of management practices on the microarthropod community of grassland. Pedobiologia 31: $339-354$

Siepel H, Vogels J, Bobbink R, Bijlsma RJ, Jongejans E, de Waal R, Weijters M (2018) Continuous and cumulative acidification and $\mathrm{N}$ deposition induce $\mathrm{P}$ limitation for the micro-arthropod soil fauna of mineral-poor dry heathlands. Soil Biol Biochem 119:128-134

Soil Survey Staff (1999) Soil taxonomy: a basic system of soil classification for making and interpreting soil surveys. $2^{\text {nd }}$ Ed. US Dept Agr, Agr Handbook 436

Sutton MA, Mason KE, Sheppard LJ, Sverdrup H, Haeuber R, Hicks WK (2014) Nitrogen deposition critical loads and biodiversity. Springer, Dordrecht

van den Berg LJL, Dorland E, Vergeer P, Hart MAC, Bobbink R, Roelofs JGM (2005) Decline of acid-sensitive plant species in heathland can be attributed to ammonium toxicity in combination with low $\mathrm{pH}$. New Phytol 166:551-564

Vitousek PM, Aber JD, Howarth RW, Likens GE, Matson PA, Schindler DW, Schlesinger WH, Tilman DG (1997) Human alteration of the global nitrogen cycle: sources and consequences. Ecol Appl 7:737750

Vogels J, Verberk WCEP, Lamers LPM, Siepel H (2017) Can changes in soil biochemistry and plant stoichiometry explain loss of animal diversity of heathlands? Biol Conserv 212:432-447

Weigmann G (2006) Hornmilben (Oribatida). Die Tierwelt Deutschlands 76. Teil, Goecke and Evers, Keltern, 1-520

Publisher's note Springer Nature remains neutral with regard to jurisdictional claims in published maps and institutional affiliations. 